\title{
Tectonic-palaeoenvironmental forcing of clay-mineral assemblages in nonmarine settings: the Oligocene-Miocene As Pontes Basin (Spain)
}

\author{
A. Sáez ${ }^{\mathrm{a}, *}$, M. Inglès ${ }^{\mathrm{b}}$, L. Cabrera ${ }^{\mathrm{a}}, \mathrm{A}$. de las Heras ${ }^{\mathrm{a}}$ \\ ${ }^{a}$ Departament d'Estratigrafia, Paleontologia i Geociències Marines, Research Group of Geodynamics and Basin Research, \\ Facultat de Geologia, Universitat de Barcelona, E-08028 Barcelona, Spain \\ ${ }^{\mathrm{b}}$ Departament de Geoquímica, Petrologia i Prospecció Geologica, Research Group of Sedimentary Petrology, Facultat de Geologia, \\ Universitat de Barcelona, E-08028 Barcelona, Spain
}

Received 17 January 2002; accepted 16 September 2002

\begin{abstract}
Two small, alluvial-lacustrine subbasins developed during the early restraining overstep stages of the Oligocene-Miocene As Pontes strike-slip Basin (NW Spain). Later, the basin evolved into a restraining bend stage and an alluvial-swamp-dominated depositional framework developed. The palaeobiological record demonstrates that the Oligocene-Miocene palaeoclimate in NW Spain was subtropical, warm and humid to subhumid. The metamorphic and igneous basin catchment yielded clay assemblages made up by kaolinite, illite and Al-smectite. Illite occurred as an original mineral in the source rock area, whereas kaolinite and Al-smectite resulted mainly from weathering of feldspar and clinochlore, respectively. This detrital primary clay assemblage remained preserved in the colluvial, alluvial fan and shallow lacustrine facies, whose early diagenesis was influenced by diluted, poorly evolved pore waters with neutral to slightly alkaline $\mathrm{pH}$. The original clay assemblage was mildly to strongly transformed under early diagenetic conditions in the lacustrine and swampy environments where significant hydrochemical and $\mathrm{Eh}-\mathrm{pH}$ changes took place. A fibrous magnesium-rich clay mineral-dominated assemblage (palygorskite and sepiolite) formed in shallow, saline lakes and palustrine zones under the influence of magnesium-rich, alkaline waters. Moreover, kaoliniteenriched assemblages formed in deep lacustrine, swamp and swamp-related alluvial zones under the influence of slightly to highly acidic pore waters. Pore water acidic conditions, characterising environments with organic matter accumulation, led to early diagenetic transformation of $\mathrm{Al}$-smectite into kaolinite. This process was relatively limited in some environments such as organic matter-rich bottoms in meromictic lacustrine zones, whereas it was pervasive in peat-forming swamp zones.

The stratigraphic relationships between the diverse clay mineral assemblages in the As Pontes Basin fill demonstrate the coeval development of rather diverse clay compositions. This clearly reflects the influence on clay assemblages of palaeoenvironmental changes forced by the morphological and tectonic evolution of the catchment-basin system. The interplay between climate and tectonic processes in the source areas did not result in major variations of the clay minerals fed into the basin. Conversely, this tectonic-sedimentation interplay influenced the evolution of the drainage and the water balance in the depositional zones, causing a complex environmental-hydrochemical evolution to occur. As a consequence, drastic early
\end{abstract}

* Corresponding author. Depto. Geologia Dinamica, Geofisica y Paleontologia, Campus de Pedralbes, Universidad de Barcelona, Barcelona 08071, Spain. Fax: +34-93-402-1340.

E-mail address: alberto@natura.geo.ub.es (A. Sáez). 
diagenetic changes affected the original clay mineral assemblages and resulted in a variety of early diagenetic assemblages. The As Pontes case study emphasises the major influence of palaeogeographical and tectonosedimentary evolution on the claymineral record in nonmarine depositional systems. The depositional record in As Pontes Basin demonstrates that morphological and tectonically forced environmental and hydrochemical changes can result in variations similar to those forced by low-order climatic changes and that, in some cases, the role of climate can be negligible.

(C) 2002 Elsevier Science B.V. All rights reserved.

Keywords: Lacustrine; Swamp; Palygorskite; Sepiolite; Kaolinite; Al-smectite

\section{Introduction}

Depositional and early diagenetic clay mineral assemblages in nonmarine basins constitute a potential record of morphological, tectonic and climatic changes on ancient continental surfaces (Webster and Jones, 1994; Armenteros et al., 1995; López and González, 1995). Nevertheless, the understanding of the evolution of these assemblages is often biased by overemphasis on the importance of palaeoclimate on clay transformation and/or neoformation (Singer, 1979, 1984; Long et al., 1997; Karakas and Kadir, 1998). In fact, source area lithology, tectonics and drainage evolution, which significantly influence continental basin hydrochemistry, can be leading factors that interact with climate and modify composition, distribution and evolution of clay mineral assemblages.

Small nonmarine basins usually have small catchment areas with few rock types. As a consequence, clay mineral assemblages can be rather homogeneous, except where significant syndepositional palaeoclimatic and/or tectonic-morphological changes affect weathering and erosion processes in the source areas or force significant palaeoenvironmental changes in the basin. These syn-depositional palaeoenvironmental changes are often related to the basin hydrological balance, which apart from climate may also depend on tectonic forcing on the basin catchment and drainage pattern. Changing depositional hydrochemistry involves varying $\mathrm{pH}$ and ionic concentrations in both surface and pore waters. All of these influence pedogenic processes and early burial diagenesis, which change the original clay signatures.

The tectonosedimentary evolution of the Oligocene-Miocene As Pontes Basin, NW Spain, comprises several stages, which can be distinguished by marked environmental and sedimentological changes throughout the stratigraphical succession in a relatively small area (Cabrera et al., 1996). Various clay mineral assemblages, interpreted solely as the result of palaeoclimatic changes (Medus, 1965; Brell and Doval, 1979), have been recorded in the As Pontes Basin fill. Nevertheless, no clear relationships have been established so far between the clay assemblages and the structural and sedimentary evolution of the basin. This paper focuses on relationships between clay mineral assemblages and palaeoenvironmental changes in the As Pontes Basin and its catchment. Processes of clay formation in the source area as well as preservation, transformation and neoformation of clay minerals in the evolving basin environments are analysed.

\section{Geological setting}

The Late Oligocene-Early Miocene As Pontes Ba$\sin$ (NW Spain) is a small basin $\left(12 \mathrm{~km}^{2}\right)$ that developed in a NW-SE oriented strike-slip fault system (Cabrera et al., 1996). The basin is bounded to the north by $\mathrm{E}-\mathrm{W}$ and NW-SE oriented thrusts, whereas the Tertiary deposits, reaching up to $400 \mathrm{~m}$ in thickness, unconformably onlap the Precambrian-Palaeozoic metamorphic Variscan basement at the southern basin margin (Figs. 1 and 2). In the basin catchment, bedrock consists mainly of slates, schists, metagrauwackes, quartzites and minor gneisses and granitoids (Fig. 1).

Sedimentation in the As Pontes Basin was closely controlled by tectonics. The Alpine north-south compression in NW Spain produced on a NW-SE oriented, km-length shear zone, which resulted in the development of laterally stepped, normal and reverse faults (Ferrús, 1998). These tectonic structures gave rise to two main depocentres, the so-called eastern (E-) 


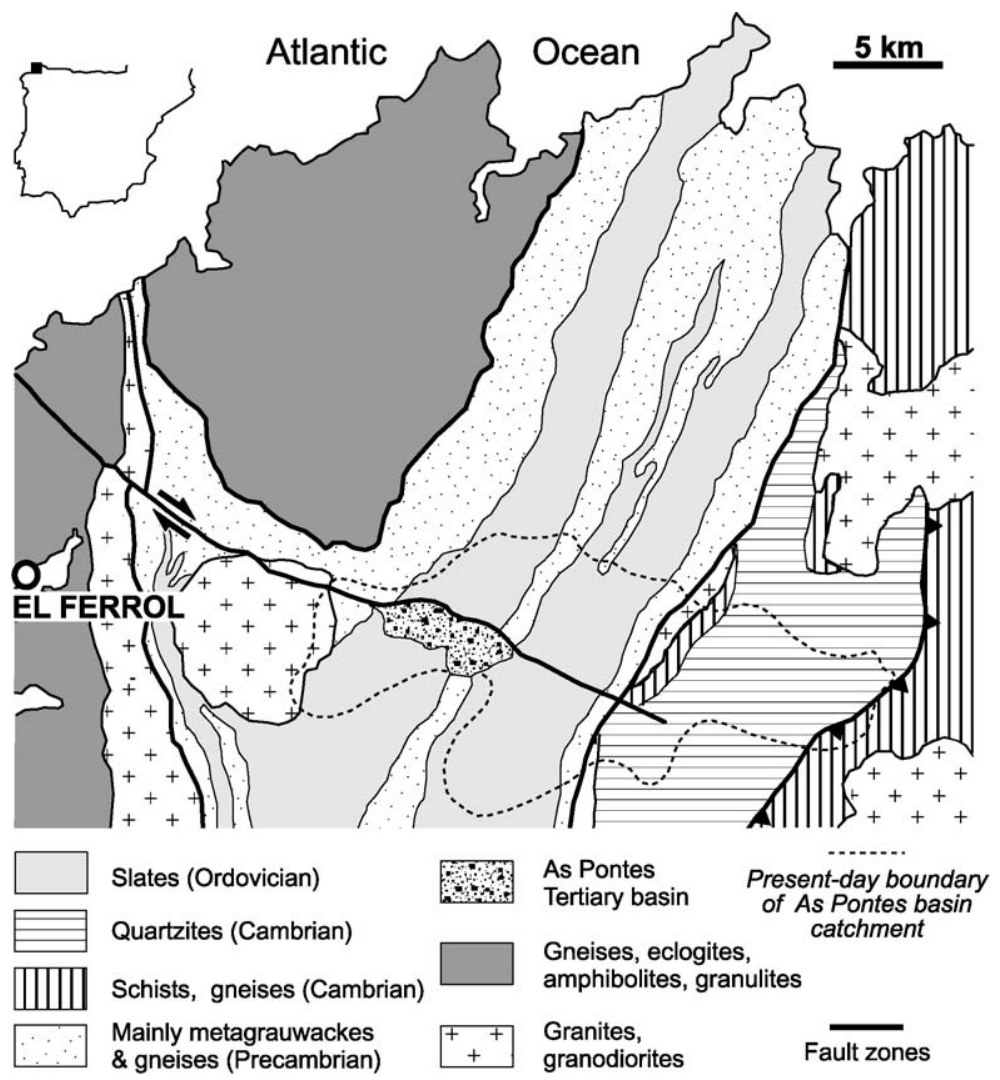

Fig. 1. Regional geological setting of the As Pontes Basin. The Precambrian and Palaeozoic rocks constitute a Variscan basement, which was affected by the Alpine deformation of the northern Iberian margin, in the western end of the Pyrenean orogen. The present basin catchment, shown as a reference, may be similar to that existing during the late stages of basin evolution.

and western (W-) subbasins, separated by a tectonically conditioned threshold. Small-sized alluvial, lacustrine and swamp depositional systems developed within these depocentres. The threshold was buried at the time the normal faults became inactive (Fig. 2b). During the later basin evolutionary stages, a strike-slip restraining bend resulted in the upper siliciclastic and coal facies, deposited in alluvial fan and swamp environments (Fig. 2b).

The palaeobiological and sedimentological record (Medus, 1965; Baltuille et al., 1992; López et al., 1993; Cabrera et al., 1994; Sáez and Cabrera, 2002) of the As Pontes Basin demonstrates that the Oligocene palaeoclimate in NW Spain was subtropical, probably with dry and rainy seasons and affected by highfrequency humid-subhumid cycles. No evidences for strong aridity can be inferred from the overall composition of the palaeofloras. These data are in agreement with the palaeolatitudinal location of Iberia during Late Oligocene-Early Miocene times (Smith, 1996; Andeweg, 2002).

The sedimentary fill of the As Pontes Basin developed over $7 \mathrm{my}$, from Late Oligocene to Early Miocene (Huerta et al., 1997). It has been split into five major stratigraphic units (Fig. 2b,c) on the basis of the relative abundance of alluvial, lacustrine and swamp deposits, their stacking pattern and geometric tectonosedimentary relationships (Cabrera et al., 1996; Ferrús, 1998). The low rank of the lignites in the As Pontes Basin provides evidence of the shallow burial conditions to which the basin fill has been experienced (Cabrera et al., 1995). This fact guarantees that the clay mineral assemblages preserved in the sedimentary successions are pri- 

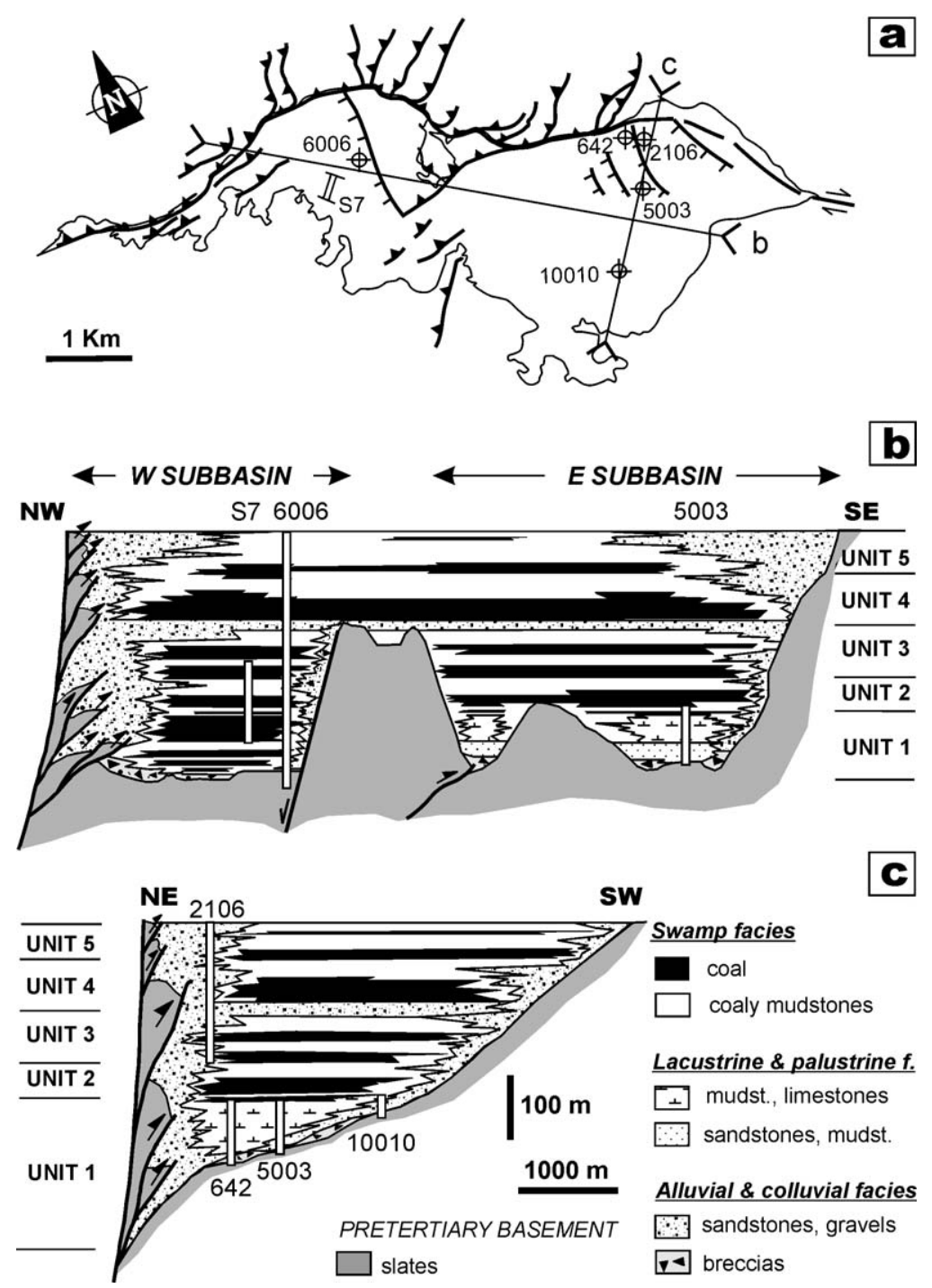

Fig. 2. (a) Geological sketch of the As Pontes Basin showing the main alpine structures that affect the basement and the location of the studied well cores and surface section (S7). (b) Longitudinal section of the Tertiary As Pontes infill showing the main stratigraphic units, sedimentary facies, basement structures and the location of the sampled sections. (c) Transverse section of the W-subbasin infill. Core wells 10010 and 5003 record mainly alluvial contributions from the southern source areas, whereas core wells 2106 and 642 record a northern and a mixed northernsouthern feeding, respectively. The longitudinal and transverse sections in $\mathrm{b}$ and $\mathrm{c}$ share the horizontal and vertical graphic scales.

mary or have underwent only very early diagenetic changes.

\section{Sampling and analytical techniques}

A total of 355 mudstone samples, mainly from five well cores and an outcrop section (Fig. 2), were collected for mineralogical analysis. The sampling was focused on the control of the clay mineralogical changes in the various alluvial, lacustrine and swamprelated systems and covered as far as possible the diverse facies.

Semiquantitative clay minerals analyses were carried out on 201 mudstone samples from diverse facies assemblages (colluvial, alluvial, palustrine-lacustrine, 


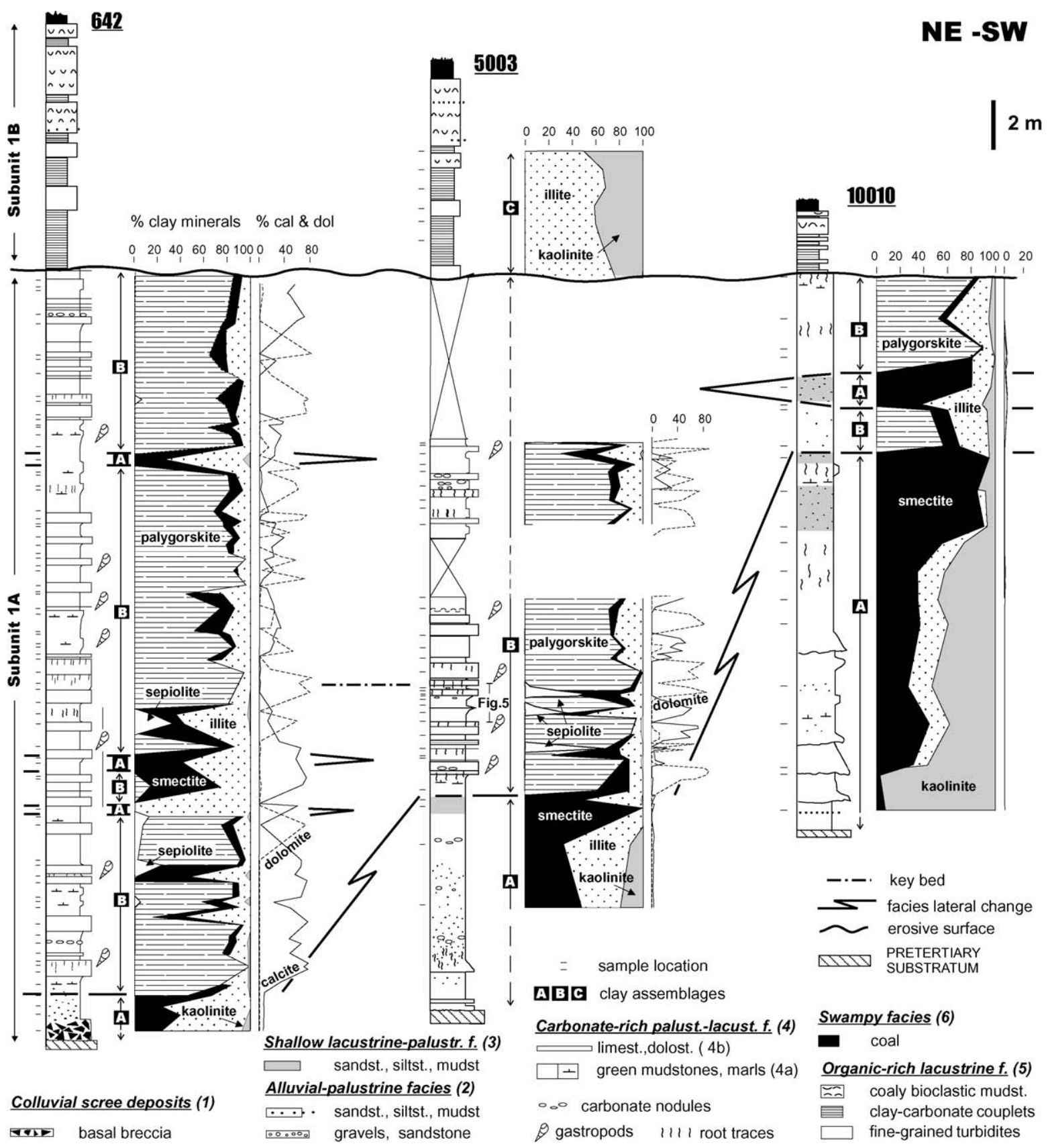

Fig. 3. Stratigraphic correlation of facies assemblages of Unit 1 between logs of the E-subbasin core wells. Relative clay mineral and carbonate percentages are represented, together with vertical and lateral relationships among the clay assemblages. Short lines on the left side of the logs indicate sample locations. Interfingering from SW to NE between the alluvial fan facies and the mixed siliciclastic-carbonate lacustrinepalustrine assemblage. The larger kaolinite content in core well 10010 is a distinctive feature compared with the low content of this mineral in core wells 642 and 5003, which may record contributions from the northern source areas. 
shallow lacustrine, deeper lacustrine and swamp). A representative portion of each sample was ground in a tungsten carbide ring mill to obtain fine powder for bulk mineralogy. A portion of each one was disaggregated and deflocculated by successive washing with distilled water. The $<2-\mu \mathrm{m}$ size fraction was separated by centrifugation. Oriented specimens were prepared for X-ray diffraction (XRD) by smearing a paste of $<2-\mu \mathrm{m}$ fraction onto a glass slide to minimize size fractionation of the clay particles (Moore and Reynolds, 1989). Identification of clay mineral phases was made after air-drying, ethylene glycol solvation and heating at $550{ }^{\circ} \mathrm{C}$ for $2 \mathrm{~h}$ the oriented mounds. All the $\mathrm{X}$-ray diffraction analyses were performed using a Siemens D500 X-ray diffractometer and $\mathrm{Cu}$ Ka radiation.

Quantitative estimation of the bulk mineralogy used the method of Chung (1974). Semiquantitative estimation of clay mineral constituents was carried out on the ethylene-glycol solvated XRD patterns using area measurements and peak intensity ratios (Schultz, 1964; Biscaye, 1965). Peak intensity ratios cited in Biscaye (1965) were used for illite, smectite and kaolinite, whereas those of Van der Marel (1966) were used for palygorskite and sepiolite. Peak superposition, mainly of illite and palygorskite, were resolved using the computer program APD (Phillips).

Additional bulk analyses of the deeper lacustrine facies (154 samples) enabled its more extensive qualitative characterization. The total organic carbon (TOC) content in some mudstone samples was determined with a NA1500 elemental organic analyser, coupled to a gas chromatograph.

Fifty selected samples of the diverse facies assemblages were further studied by scanning electron microscopy (SEM; Hitachi S 2300 and JEOL JSM 840 equipped with an AN-10.000 LINK energy dispersive $\mathrm{X}$-ray microanalyser). Seven samples from carbonaterich lacustrine-palustrine facies were observed and analysed with transmission electron microscopy (Hitachi H-800 MT with H-8010 STEM and SEM system and KEVEX EDS microanalyser). Analyses were carried out in STEM mode and, to minimize element diffusion, the electron was beam rastered over an area of the particle (Peacor, 1992). Quantitative microanalyses of illite, smectite and palygorskite were carried out in order to determine mean structural formulae.
The carbonate bearing beds and laminae of Unit 1 were sampled from the same core-wells (Figs. 2 and $3)$. The quantitative estimation of carbonate content was carried out by decomposition of the samples with $\mathrm{HCl}$ and titration of excess acid with $\mathrm{NaOH}$ using a 702SM Trinitro Automatic Titrator. Bulk mineralogical composition of the carbonate samples was determined by X-ray diffraction (XRD) using a SIEMENS D500 diffractometer. The composition of carbonate samples was also determined by standard XRD semiquantitative methods (Chung, 1974).

\section{Basin fill facies and basin evolution}

A variety of colluvial, alluvial, shallow to deep lacustrine and marsh-swamp facies associations developed in As Pontes Basin. A short description and interpretation of the depositional and early diagenetic characteristics of these facies associations is provided to give an overview of the major basin fill characteristics and the overall palaeoenvironmental evolution.

\subsection{Colluvial scree facies assemblage (1)}

Up to a few metres thick, lenticular, fine-grained, matrix to clast-supported breccias occur locally at the bottom of the basin infill (Fig. 2b; $0-1 \mathrm{~m}, \log 642$, in Fig. 3). The breccia framework is made up by pebbleto cobble-size slate and quartz clasts up to a few centimetres in size. Monomictic lenses of quartz breccias and conglomerates with subangular clasts are locally recognised. The breccias are very immature texturally and record short-transport, colluvial scree deposition fed directly from the metamorphic and igneous substratum. The clay-dominated matrix includes illite, smectite and kaolinite.

\subsection{Alluvial fan facies assemblages (2)}

The alluvial fan assemblages range from proximal fine-grained, quartz-dominated conglomerates, wackes and coarse-grained sands to middle and distal finegrained sandstones and siliciclastic mudstones. Small alluvial fans, $1 \mathrm{~km}$ in radius, developed during the early evolutionary stages of the basin and later coexisted with larger fans, which in some cases reached up 
to $3.5 \mathrm{~km}$ in radius (Fig. 2). The evolution of the alluvial fan systems was controlled mainly by the headward extent of the catchment, the increasing depositional surface and varying subsidence in the basin. The diverse stacking trends observed in the alluvial assemblages record the shift, spreading and retreat of fan systems, either at the foot of basin margin tectonic scarps or adjoining the southern source areas (Fig. 2b,c). Broadly, three main depositional situations have been distinguished taking into account source area location, radial extent of the fans and relationships with organic-rich deposits (coals and coaly mudstones):

(a) Alluvial fan deposits fed from the southern source areas occur in wells 5003 and 10010 (Fig. 3). These belong to the lower part of Subunit $1 \mathrm{~A}$ in the E-subbasin and correspond to an evolutionary stage characterised by absence of peat-forming marsh-swamp environments (Fig. 2). Consequently, these alluvial deposits do not show lateral or vertical transitions to either coal seams or dark-coloured mudstones. Mudstones are scarce in the proximal and middle fan facies assemblages, which are dominated by grey to pale green massive lithic wackes and quartzose sandstones, which locally contain floating out-of-size quartz granules. Distal alluvial facies consist dominantly of pale green siliciclastic mudstones interbedded with thin, fine-grained sandstone beds. Thin horizons of carbonate nodules (high magnesium calcite, HMC) and root traces in the distal mudstone-dominated beds record mild early pedogenic diagenesis, which took place in palustrine zones where pore waters were neutral to slightly alkaline and with a relatively high $\mathrm{Mg} / \mathrm{Ca}$ ratio. Illite, kaolinite and smectite are the major clay minerals recorded in these assemblages; minor traces of chlorite occur in the lowermost, basin bottom-related samples (Fig. 3).

(b) Alluvial fan deposits fed from the northern source areas are well developed in the lower part of well 642 (Fig. 3 Subunit 1A, E-subbasin) and in well 2106 (Fig. 4 Units 2-5 E-subbasin). The siliciclastic mudstone beds recorded in these wells are massive, green to grey and dark brown. The colour depends mainly on organic matter content, which increases towards the middle- distal alluvial fan zone facies. Reddish shades occur rarely in the proximal-middle alluvial facies recognised in well 2106. In well 642, the thin middle-distal alluvial deposits overlying the colluvial assemblage show similar characteristics and mineralogy to those observed in wells 5003 and 10010 (Fig. 3). In well 2106, minor coal seams and dark-coloured, organic-rich clays occur interbedded with the alluvial fan facies. Moreover, the stratigraphic framework (Fig. 2) shows that a significant proportion of the alluvial facies are related to coal seams. This fact suggests that during deposition and early diagenesis, the alluvial materials were influenced by acidic pore waters generated in marsh-swamp zones where peat accumulation took place. Major kaolinite, illite and minor smectite have been determined in the alluvial mudstone deposits.

(c) Alluvial fan deposits also accumulated at the foot of the normal fault scarp that bounded the western side of the basin threshold (Fig. 2). These deposits are well observed in well 6006 (Fig. 4, Units 1-5, $\mathrm{W}$-subbasin), where the massive mudstone beds are green, grey, dark brown and black, containing up to $40 \%$ organic matter. The percentage of mudstones with high organic contents increases towards the inner basin zones where marshswamp sedimentation was dominant (see facies assemblage 6). In well 6006, the proximal-middle to distal alluvial fan successions of Units 1-5 closely interfinger with coal seams and darkcoloured, organic-rich clays. In view of this geometric relationship, the alluvial fan facies evolved under the influence of acidic pore water conditions. Illite and kaolinite in varying proportions are the major clay minerals recorded in the alluvial mudstones, whereas smectite is very rare (Fig. 4).

\subsection{Shallow terrigenous lacustrine facies assemblage} (3)

Green to pale grey, massive siliciclastic mudstones and sandy mudstones related to alluvial facies occur in the Subunit 1A of the E-subbasin (Fig. 3, well 10010). These deposits have locally yielded scarce fossil remains of limnic organisms (ostracods). Moreover, some shelly green mudstone beds occur interbedded 


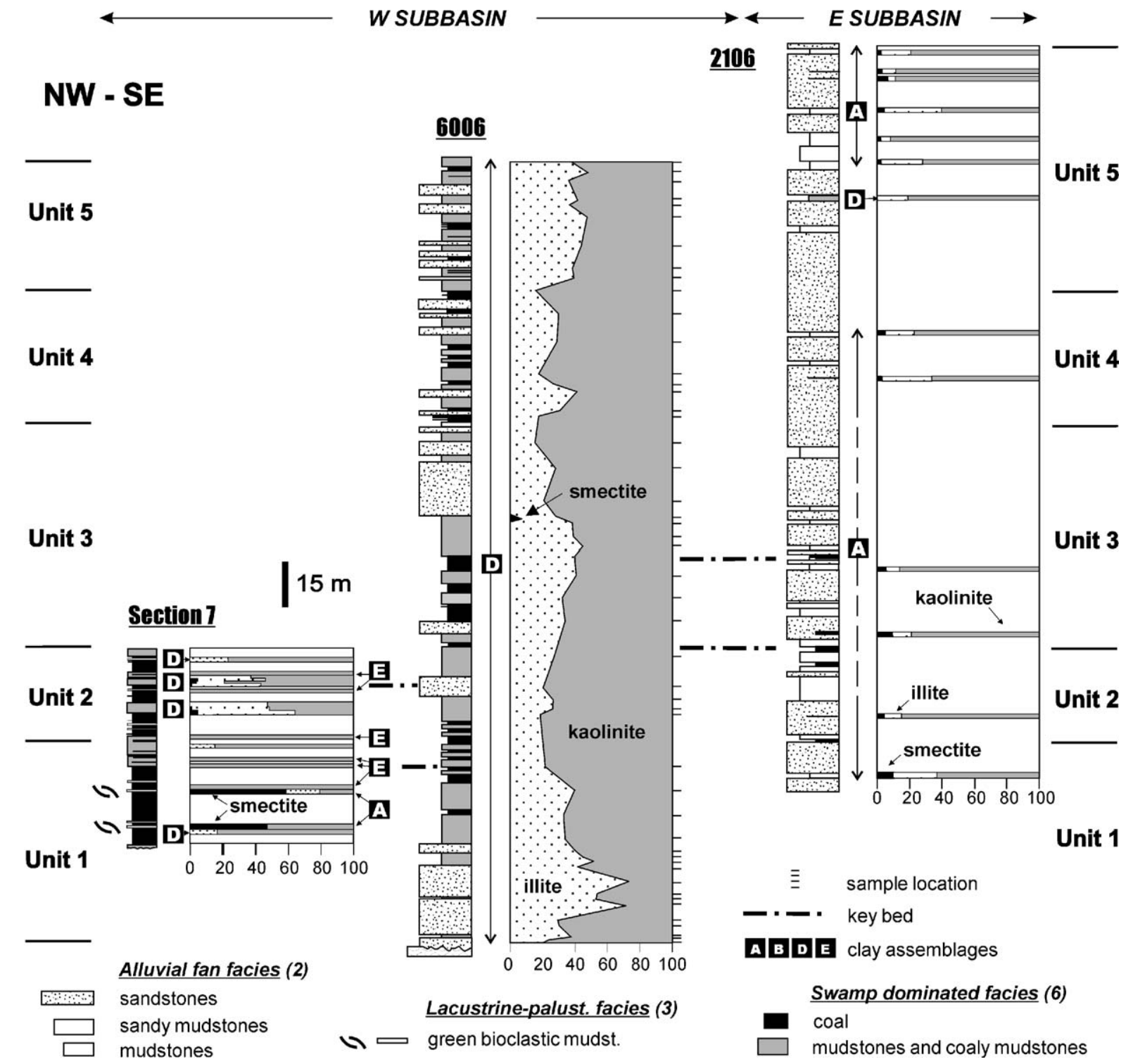

Fig. 4. Stratigraphic correlation of facies assemblages (Units 1-5). Correlation between core well 2106 (W-subbasin), core well 6006 and surface Section 7 (E-subbasin) is shown. Clay mineral abundance and clay assemblages are shown. Note that smectite is a minor, widespread component in the proximal to middle alluvial fan facies in core well 2106. Kaolinite is the sole component in some of the studied swamp facies samples. Short lines on the right side of the logs indicate sample locations.

within a thick coal seam, which is present in Unit 1 of the W-subbasin (Section 7, Fig. 4). The mudstones are up to a few decimetres thick, massive, organic matterpoor and yielded widespread freshwater gastropod (Planorbidae) shell fragments, which are preserved as calcite.
Facies assemblage 3 records brief lacustrine episodes. These are characterised by siliciclastic supply and occasionally interrupted peat deposition in the swamp environments. The occurrence of freshwater gastropod remains and the preservation of calcitic shells suggest that neutral to slightly high $\mathrm{pH}$ con- 
ditions prevailed during the accumulation and early diagenesis of these shallow lake deposits. Illite, kaolinite and significant amounts of smectite are the major clay minerals recorded in the siliciclastic mudstone bed facies. This clay mineral assemblage is similar to that observed in some of the alluvial fan facies.

\subsection{Cyclical mudstone-carbonate palustrine-lacus- trine facies assemblage (4)}

These deposits are largely present in Subunit 1A of the E-subbasin and comprise mainly green siliciclastic mudstones and marls, alternating with whitish dolostone and limestone beds (Fig. 3). Both mudstones and carbonates make up a few decimeter- up to a few meterthick cycles, with a maximum frequency of about $0.5 \mathrm{~m}$ (Fig. 5).

The green mudstones and marls (Facies 4a) are massive to vaguely laminated, organic-poor deposits (TOC 1\%), which were mainly contributed from fringing distal alluvial fan zones (samples 1, 4, 5, 8 in Fig. 5). HMC, LMC and dolomite characterise the carbonate-rich, locally nodular mudstones suggesting pore waters with high $\mathrm{Mg} / \mathrm{Ca}$ ratios. Moreover, the mudstones often yield athalassic faunal assemblages (Anadón, 1989; Plaziat, 1993) including monospecific accumulation horizons of Hydrobia and other gastropods (Potamides). These faunal assemblages suggest saline water conditions, which could be a result of negative water balance periods. Poorly preserved, corroded sponge spicules and diatom frustules also occur, suggesting relatively high $\mathrm{pH}$ in the pore waters that favoured early diagenetic silica release. TEM observations reveal the presence of micrometric opal. The whitish carbonate beds (Facies $4 b$ ) are massive, micritic and show greenish shades depending on their clay content (samples 2, 3, 6, 7; Fig. 5). They often display pedogenic features such as root traces, vertical and horizontal skew planes and nodules suggesting subaerial exposure. Dolomite and subordinate HMC and LMC are the most common carbonates. Major palygorskite, illite and minor smectite and kaolinite are the most significant clay minerals and sepiolite has been locally recognised (Fig. 3).

Shallow, closed-drainage lacustrine zones developed in the E-subbasin during the earlier stages of sediment fill when water level changes where frequent. Highstand lake levels resulted in expanded shallow holomictic lacustrine zones and subaqueous

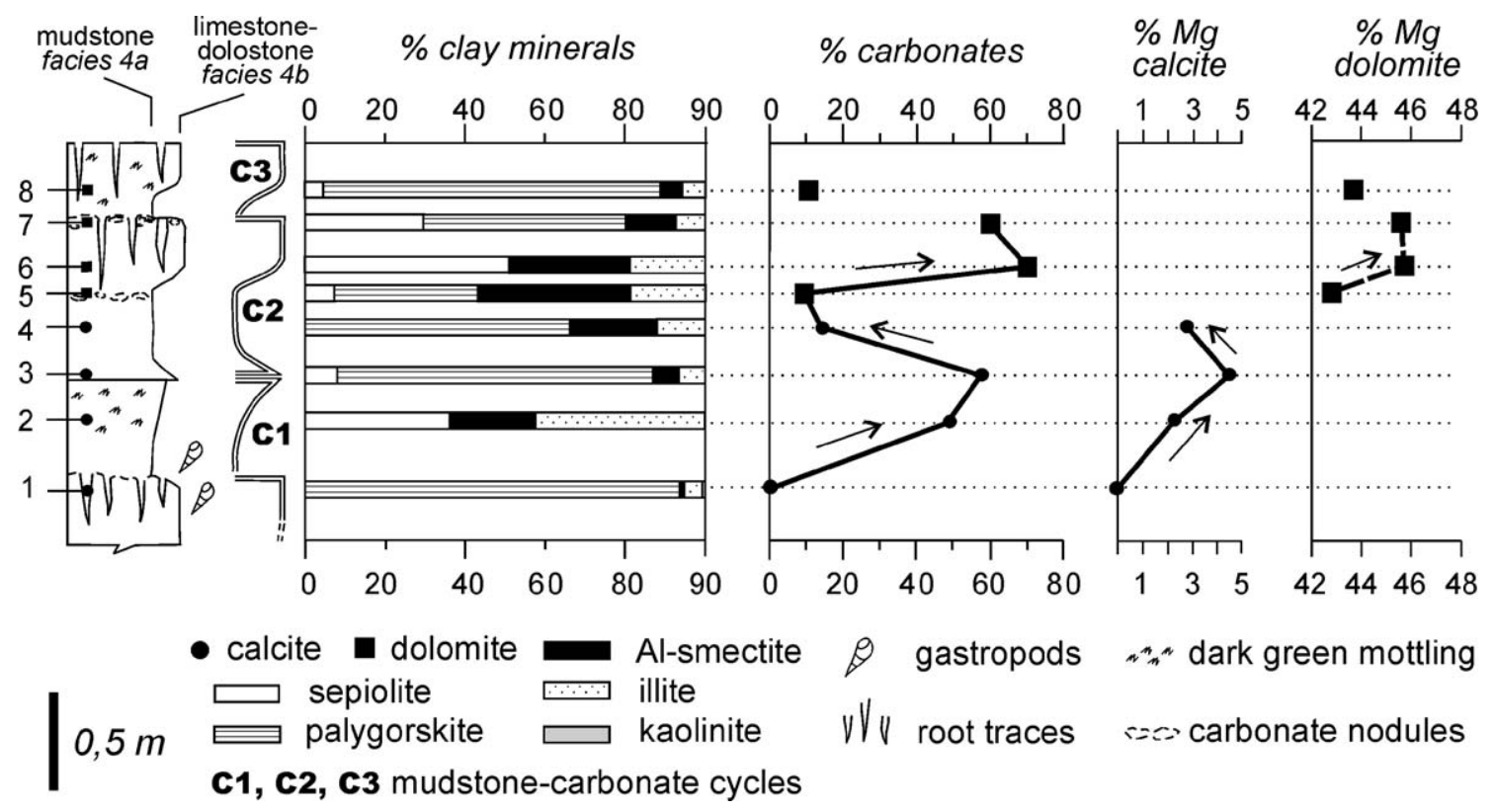

Fig. 5. Mudstone-carbonate cycles in the palustrine-lacustrine facies assemblage of Subunit 1A (see stratigraphic location in Fig. 3, core well 5003). Sepiolite is usually related to the carbonate-rich beds, particularly those showing higher magnesium. See text for further explanation. 
deposition of massive green mudstones and marginal palustrine carbonates, whereas lowstand lake levels gave rise to lacustrine contraction and extensive deposition of palustrine carbonates even under subaerial conditions. Persistence of this depositional framework resulted in mudstone/carbonate cycles. These record repeated high-frequency deepening-shallowing processes linked to expansion and contractions of the lake featuring low-gradient, marginal lacustrine ramps (Sáez and Cabrera, 2002). The occurrence of fibrous clay minerals, palygorskite and sepiolite, which are exclusive to these facies, is interpreted as a result of highly alkaline, magnesium-rich pore waters, which characterised the early lake systems developed in the E-subbasin.

\subsection{Organic-rich, deep lacustrine facies assemblage} (5)

This facies assemblage comprises up to 12-m-thick deposits (Subunit 1B), which overlie the widespread erosive surface located at the top of Subunit 1A (Fig. 3). The lower part of the sedimentary successions comprises fine-grained turbidites, mud-dominated shales and thin clay-carbonate rhythmites that were deposited in offshore lacustrine zones up to $15 \mathrm{~m}$ deep. They grade upwards into bioclastic coaly mudstones deposited in lacustrine bench environments (Sáez and Cabrera, 2002).

The offshore shales have TOC contents ranging from $12 \%$ to $33 \%$. Low and high magnesium calcite and minor siderite make up the carbonate laminae in the rhythmite facies. The isotopic composition of the primary carbonates in these rhythmites suggests that the lake system was closed (Sáez and Cabrera, 2002). These shales and rhythmites yielded a distinctive freshwater palaeobiota (gastropods, frogs), suggesting that dissolved solids remained low. The high organic matter contents determined in the mud-dominated shales suggests that their early diagenesis could be influenced by acidic pore waters. Illite and kaolinite are the only major clay minerals recognised in these deposits (well 5003, Fig. 3).

The widespread occurrence of well-laminated facies and the good preservation of organic matter indicate that the lake water column was perennial and deep enough to allow long-term water stratification (meromixis). The microlaminated clay-carbonate couplets suggest seasonal and/or multiannual to decennial, climatically forced limnological changes (Sáez and Cabrera, 2002).

\subsection{Swamp coal facies assemblage (6)}

The lignite seams in the As Ponte Basin show a large variety of petrological and mineralogical features, which have been widely described (Cabrera et al., 1995; Huerta, 1998). Most of the seams are humic coals although some bright, liptinite-dominated coals also occur. The pure coal seam facies grade laterally and vertically into coaly mudstones. Kaolinite is the major and often single clay mineral in these facies (e.g. in five samples of Section 7, Fig. 4), whereas minor illite occurs locally.

\subsection{Basin evolution}

Deposition in the As Pontes Basin started with the development of two isolated subbasins. The E-subbasin was slightly larger than the western one and received more water contributed by a larger catchment area, as shown by heavy mineral assemblages in the alluvial fan facies (Barsó et al., 2000). The saline lacustrine-palustrine mudstone-carbonate cycles of Subunit $1 \mathrm{~A}$ suggest that the water balance was variable and often negative in this subbasin that was hydrologically closed in the early stages of basin evolution. As a result, shallow, alternately fresh and saline lacustrine-palustrine zones developed and solute-rich surface and shallow pore waters became common. In the W-subbasin, the hydrological balance was positive. This fact enabled the development of swamps and shallow lacustrine zones, but no significant dissolved solids concentration indicative of a closed drainage was attained in this setting. Later on the headward spread of the catchment drainage caused an increase in water input, resulting in the development of persistent swamp-shallow lacustrine zones in the $\mathrm{W}$-subbasin and a relatively deep lacustrine zone in the E-subbasin, recorded by deposits of Subunit 1B. Dilution of the lacustrine waters and development of meromixis in the E-subbasin accompanied this process. The absence of a depositional record of open lacustrine water bodies in the $\mathrm{W}$-subbasin contrasts with the relatively large development of lacustrine deposits in the E-subbasin. This was probably due to 
the larger extent of the catchment that fed the Esubbasin.

The later evolutionary stages of the basin were characterised by decreasing sedimentary accommodation space and changing siliciclastic contributions as recorded from stratigraphic Units $2-5$. This situation led to a depositional framework made up by fringing alluvial fans that graded laterally into swamp zones where no major open water bodies developed (Cabrera et al., 1995; Huerta, 1998).

\section{Clay mineral assemblages: composition and distribution}

The mean structural formulae of the more abundant minerals (illite, smectite and palygorskite) in the studied sections have been deduced from analysis of seven samples (Table 1). In each sample, 20 spot chemical analyses for each mineral were carried out.

The STEM/EDX analysis showed that all the smectites were dioctahedral with substitution of silicon by aluminium up to 0.24 atoms per half unit cell. In the octahedral layer, smectite shows substitution of aluminium by magnesium and iron, and potassium is the main interlayer cation. This corresponds to a beidellite-like composition (Guven, 1988) and in particular to the average beidellite described by Mayayo et al. (2000). In some cases, the recorded potassium content suggests some illite interlayering. Structural formulae determinations confirmed that all the smectites were of beidellite type. The smectite grain size is variable and predominantly $<1 \mu \mathrm{m}$ with less abundant $2-3 \mu \mathrm{m}$ grains displaying characteristic curled borders.

Table 1

Average structural composition of illite, smectite and palygorskite in the clay mineral assemblage $B$ (palustrine-lacustrine facies assemblage, Subunit 1A, E-subbasin)

\begin{tabular}{|c|c|c|c|c|c|c|c|c|}
\hline & \multicolumn{3}{|c|}{ Interlayer } & \multicolumn{3}{|c|}{ Octahedral } & \multicolumn{2}{|c|}{ Tetrahedral } \\
\hline & $\mathrm{Ca}$ & $\mathrm{K}$ & $\mathrm{Na}$ & $\mathrm{Al}$ & $\mathrm{Mg}$ & $\mathrm{Fe}$ & $\mathrm{Si}$ & $\mathrm{Al}$ \\
\hline Palygorskite & 0.34 & 0.16 & 0.13 & 1.41 & 1.66 & 0.53 & 7.83 & 0.17 \\
\hline Illite & 0.03 & 0.73 & 0.00 & 1.55 & 0.19 & 0.23 & 3.42 & 0.58 \\
\hline Smectite & 0.09 & 0.12 & 0.04 & 1.50 & 0.32 & 0.24 & 3.76 & 0.24 \\
\hline
\end{tabular}
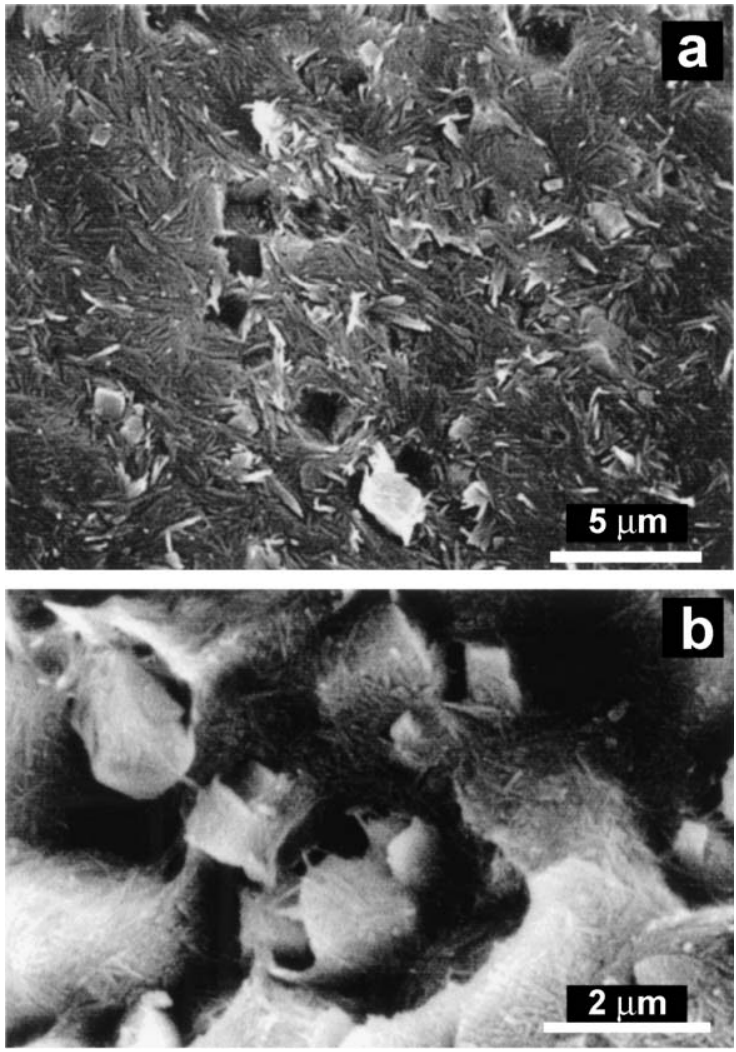

Fig. 6. (a) Palygorskite mats with scattered rhombohedral dolomite crystals in mudstone from the cyclically arranged palustrinelacustrine assemblage (E-subbasin). (b) Palygorskite fibers coat dolomite crystals and fill the intercrystalline porosity in the dolostones of subunit 1A (E-subbasin).

Analyses of the palygorskite reveal a quite homogeneous composition that is calcium-rich in comparison with other palygorskite compositions cited in the literature as summarised by Galán and Carretero (1999). The average structural formula is shown in Table 1. SEM observations indicate that in the mudstones and marl beds palygorskite consists of fibers $1-2 \mu \mathrm{m}$ long, which occur mainly as mats including scattered micron-sized dolomite rhombohedrons (Fig. 6a) and calcite with no well-developed faces. In the dolostone beds, palygorskite mats coat the dolomite crystals (Fig. 6b).

Illite is essentially homogeneous in both tetrahedral and octahedral layers. The substitution of $\mathrm{Si}$ by $\mathrm{Al}$ in the tetrahedral layer is about 0.7 atoms per half unit cell (Table 1). 


\subsection{The clay mineral assemblages}

Five major assemblages, which show a diversity of compositions and include diverse proportions of kaolinite $(\mathrm{K})$, illite $(\mathrm{I})$, smectite $(\mathrm{Sm})$, palygorskite $(\mathrm{Pal})$ and sepiolite (Sep) can be established in the As Pontes Basin (Fig. 7).

\subsubsection{Assemblage A: $K, \mathrm{Sm}, I$}

This clay mineral assemblage consists of kaolinite, aluminous smectite (Al-smectite) and illite that occur in variable proportions. It is the common clay assemblage in the colluvial and the alluvial fan successions and in the thinly bedded, shallow, freshwater lacustrine mudstone deposits. Kaolinite is relatively more abundant in core wells close to the southern basin margin (Fig. 3).

\subsubsection{Assemblage B: Pal, I, Sm (K), Sep local}

Palygorskite $(60-80 \%)$, illite $(20-30 \%)$ and Alsmectite $(5-10 \%)$ are the major components. Up to 144 clay samples from carbonate-rich palustrinelacustrine deposits in the E-subbasin enabled characterisation of this assemblage (Fig. 3). Kaolinite occurs as a very minor component in wells close to the northern basin margin (e.g. well 642). However, this mineral is quite common, although in percentages lower than $10 \%$, in well 10010 , located close to the southern basin margin. Sepiolite content ranges from $5 \%$ to $30 \%$ in some samples from well 642 , whereas it reaches up to $50 \%$ in some samples from well 5003 (Fig. 3).

\subsubsection{Assemblage $C: I, K$}

This clay assemblage is characterised by presence of illite and kaolinite as major minerals. The illite and kaolinite diffractograms in this assemblage display sharper peaks than in assemblages $\mathrm{A}$ and $\mathrm{B}$. The assemblage is restricted to the thin, laminated deep lacustrine deposits. Semiquantitative analysis revealed that illite $(50-75 \%)$ is usually more abundant than kaolinite $(25-50 \%)$, although in some cases both minerals show similar percentages in the samples (e.g. well 5003 in Fig. 3).

\subsubsection{Assemblage D: $K, I(\mathrm{Sm})$}

This clay assemblage is characterised by a clear predominance of kaolinite and illite, with minor presence or even absence of smectite. Both kaolinite and illite show sharp diffraction peaks. This assemblage has been recognised in proximal to distal alluvial-fan facies associations that are closely related

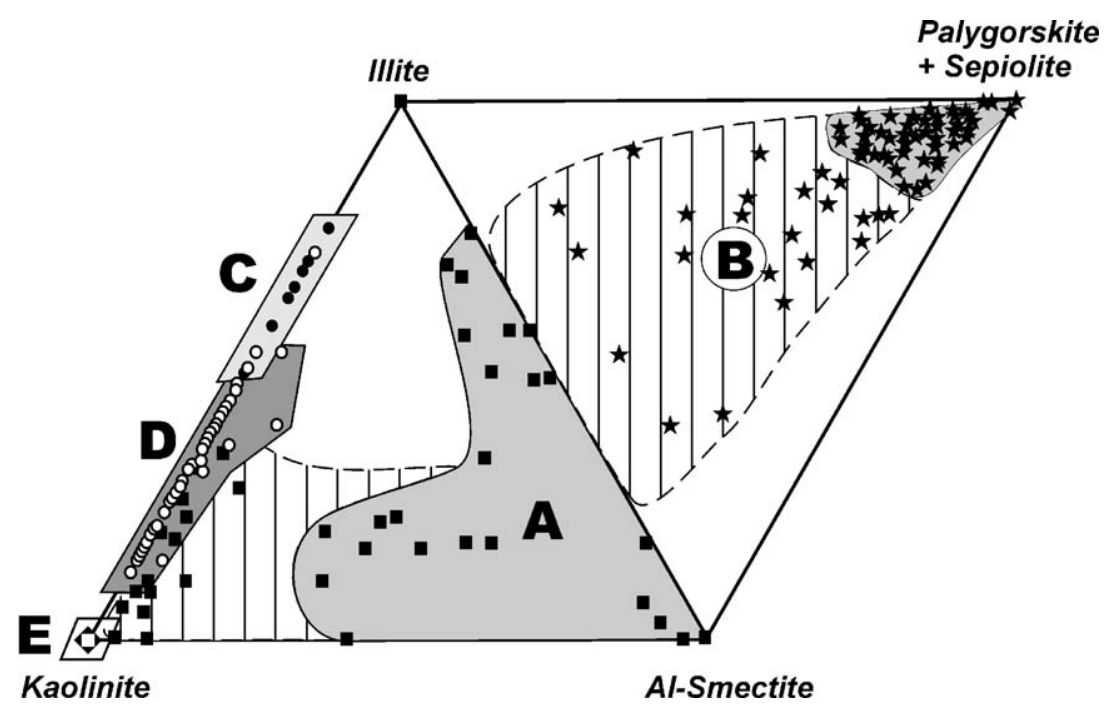

Fig. 7. Clay mineralogical composition of the mudstone deposits in the As Pontes Basin. The samples cluster in five different clay mineral assemblages indicated by capital letters A to E. The areas with vertical lines indicate transitions in composition between the different clay assemblages. The symbol that represents the clay assemblage $\mathrm{E}$ in the kaolinite vertex $(\sim 100 \%$ kaolinite $)$ corresponds to 134 coal samples analysed by Huerta (1998). 


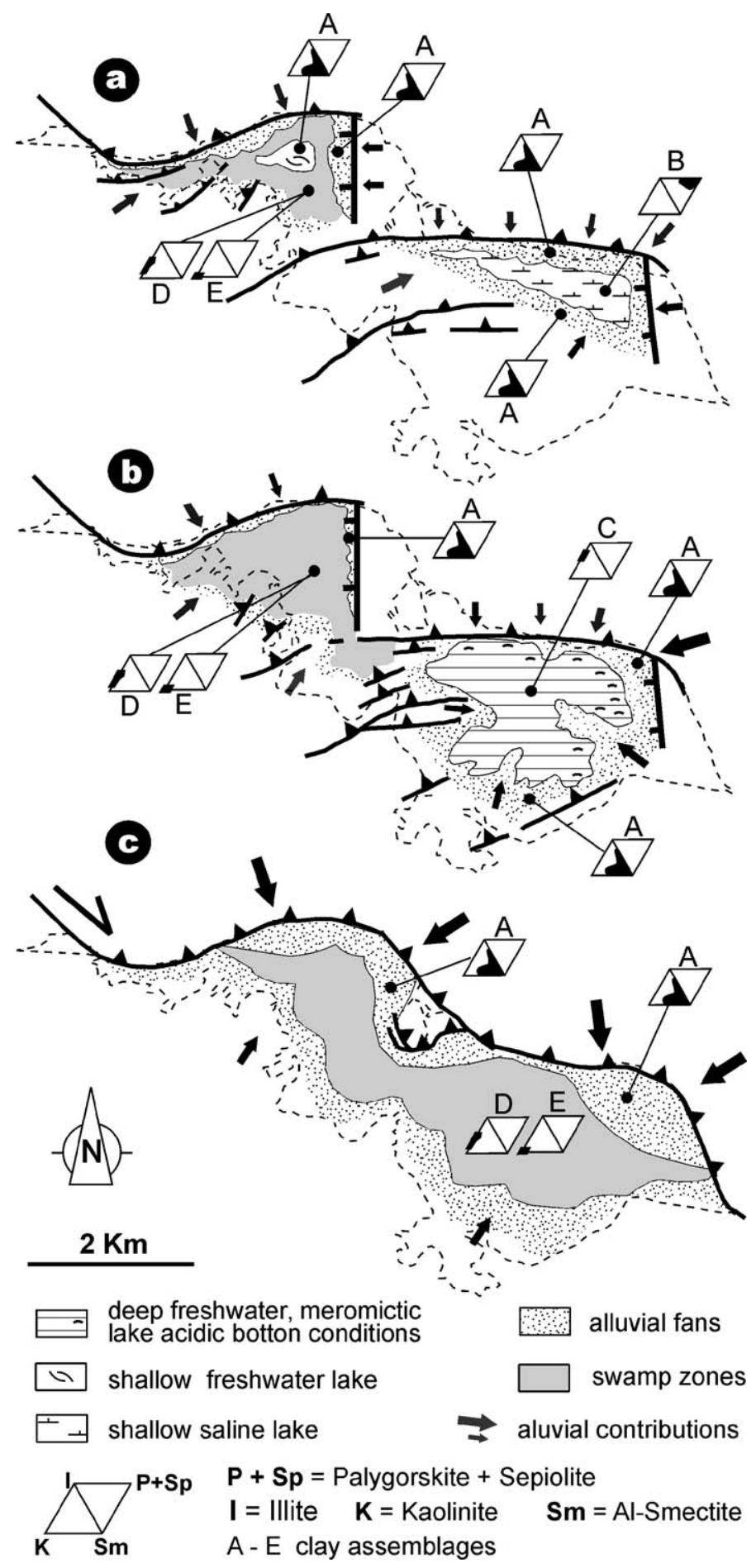

Fig. 8. Palaeogeographic sketches showing the sedimentary environments and clay mineral assemblages (parallelograms), in the three main evolutionary stages of the As Pontes Basin. (a) Subunit 1A stage; (b) Subunit 1B stage; (c) Units 2-5 stage. See text for further explanation. These maps represent the maximum spread of lacustrine and swamp environments in the basin. 
to coal-bearing successions accumulated in swamp, peat-forming environments. The coaly mudstones deposited in the more distal alluvial environments are characterised by high kaolinite contents (usually more than $60 \%$ ) and minor illite. The illite content is a little higher in coarse-grained siliciclastic deposits, as recorded in well 6006 (Fig. 4).

\subsubsection{Assemblage E: $K(I)$}

This clay assemblage is characterised by predominance of kaolinite, with minor presence or even absence of illite. Coal seams and coaly mudstones deposited in swamp environments usually yield this clay mineral assemblage (Section 7, Fig. 4). More extensive qualitative analysis of coaly, organic-rich facies were carried out by Huerta (1998). Among the 134 samples studied by this author, 74\% yielded kaolinite as the only clay mineral, whereas the remaining $26 \%$ of the samples included small amounts of illite. The kaolinite crystallinity was larger in the coal seams that displayed minor siliciclastic content.

\subsection{Mineralogical changes, vertical and lateral relationships between the assemblages}

The five clay mineral assemblages described above display some variations in the occurrence and percentages of their major and minor minerals (Fig. 7). The deposits containing clay mineral assemblage A show minor to significant kaolinite content changes. Moreover, a clear upward decrease of kaolinite, coeval to an increase of smectite, is recorded in wells 10010 and 5003 (Fig. 3).

The deposits containing clay mineral assemblage B shows also minor variations of illite and kaolinite contents. Nevertheless, the most significant changes correspond to variations of palygorskite and sepiolite contents. A remarkable decrease of smectite is recognised in sections where assemblage B-bearing deposits overlie assemblage A dominated facies (Fig. 3). Moreover, detailed analysis of the high-frequency mudstone-carbonate cycles in facies assemblage 4 shows a loose correlation between carbonate and sepiolite contents (Fig. 5). Thus, mud-dominated facies, showing less than $15 \%$ of carbonate, are barren or nearly barren of sepiolite (Fig. 5, samples 1, 4, 5 and 8). Moreover, most of the carbonate-rich beds (e.g. marls and limestone-dolostone beds with more than $50 \%$ of carbonate) show sepiolite contents higher than 30\% (samplea 2, 6 and 7 in Fig. 5). Thus, sepiolite occurs related both to dolostones and limestones. In cycles $\mathrm{C} 1-\mathrm{C} 2$, the increase and decrease of magnesium in calcite and dolomite correlates with the sepiolite and the carbonate content (Fig. 5).

Finally, the deposits containing clay mineral assemblages C, D and E (Fig. 7), which are characterised by increasing contents of kaolinite in relation to other clay minerals, show minor to significant variations of the kaolinite/illite ratio (Figs. 3 and 4).

The stratigraphic-depositional framework in the As Pontes Basin provides evidence that both presence and relative dominance of the clay mineral assemblages changed through the successive stages of basin evolution, and the assemblages display abundant lateral and vertical transitions (Fig. 8). The largest variation in of sedimentary facies and clay mineral assemblages occurred during deposition of Unit 1 (Fig. 8a,b). The diversity of clay assemblages decreased drastically through deposition of Units $2-5$, which was characterised by widespread accumulations of alluvial and swamp related deposits (Fig. $8 \mathrm{c})$.

In the E-subbasin, the clay assemblages $\mathrm{A}$ and $\mathrm{B}$ were partly coeval (Fig. 8a). The stratigraphic-sedimentological framework reflects a southward spreading of shallow lacustrine-palustrine environments, which overlie and interfinger alluvial-dominated facies (Figs. 2 and 3). The clay assemblage C, mainly present in deep lacustrine deposits, usually overlies assemblage B-dominated successions, recording a major mineralogical change. The observed stratigraphic relationships suggest that the formation of assemblage $\mathrm{C}$ was coeval with the marginal alluvial fan deposits characterised by assemblage A (Fig. 8b).

In the $\mathrm{W}$-subbasin, the clay mineral assemblages recorded in Unit 1 differ from those of the same unit in the E-subbasin. The clay assemblages A, D and E were also coeval, recording the close stratigraphic and genetic relationships between alluvial and swamp depositional environments (Fig. 8c).

\section{Discussion: origin of the clay assemblages}

The origin of the clay mineral assemblages distinguished in the sedimentary fill of the As Pontes Basin 
may be explained as a result of the interplay of tectonic and climatic constrains. Both climate and tectonic relief influenced weathering and erosion processes in the catchment areas, thereby controlling clastic and solute inputs to the basin. Diagenetic changes of the clay mineralogy in the basin were mainly driven by its hydrochemical and environmental basin evolution (Fig. 9).

6.1. The source area contributions and the clay assemblages in the colluvial, alluvial palustrine and shallow freshwater lacustrine facies

Subtropical, warm humid to subhumid climatic conditions prevailed in NW Iberia from Late Rupelian to Early Aquitanian (Medus, 1965; Baltuille et al., 1992). This warm climatic regime enhanced the development of a relatively dense plant cover in the basin and the surrounding source areas, although some open, less densely vegetated landscapes could also develop. Warm temperatures and relatively high, although probably seasonal, rainfall regime should favour extensive weathering of the metamorphic basement and significant solute and detrital contributions, including clay minerals. Tectonic uplift of the catchment areas also resulted in high erosion rates.

The metamorphic and igneous rocks forming the basin catchment during the Late Oligocene and Early Miocene were similar to those cropping out at the present (Fig. 1). This fact suggests that the Tertiary hydrochemistry of the catchment system is comparable to the recent hydrochemistry. Accordingly, the dominant mineral components of these parent rocks (quartz, K-feldspars, plagioclase, biotite, muscovite and clinochlore) were the major source for solute and clastic input to the basin.

The $\mathrm{K}+\mathrm{Sm}+\mathrm{I}$ assemblage (clay mineral assemblage A) recognised in the colluvial facies that directly

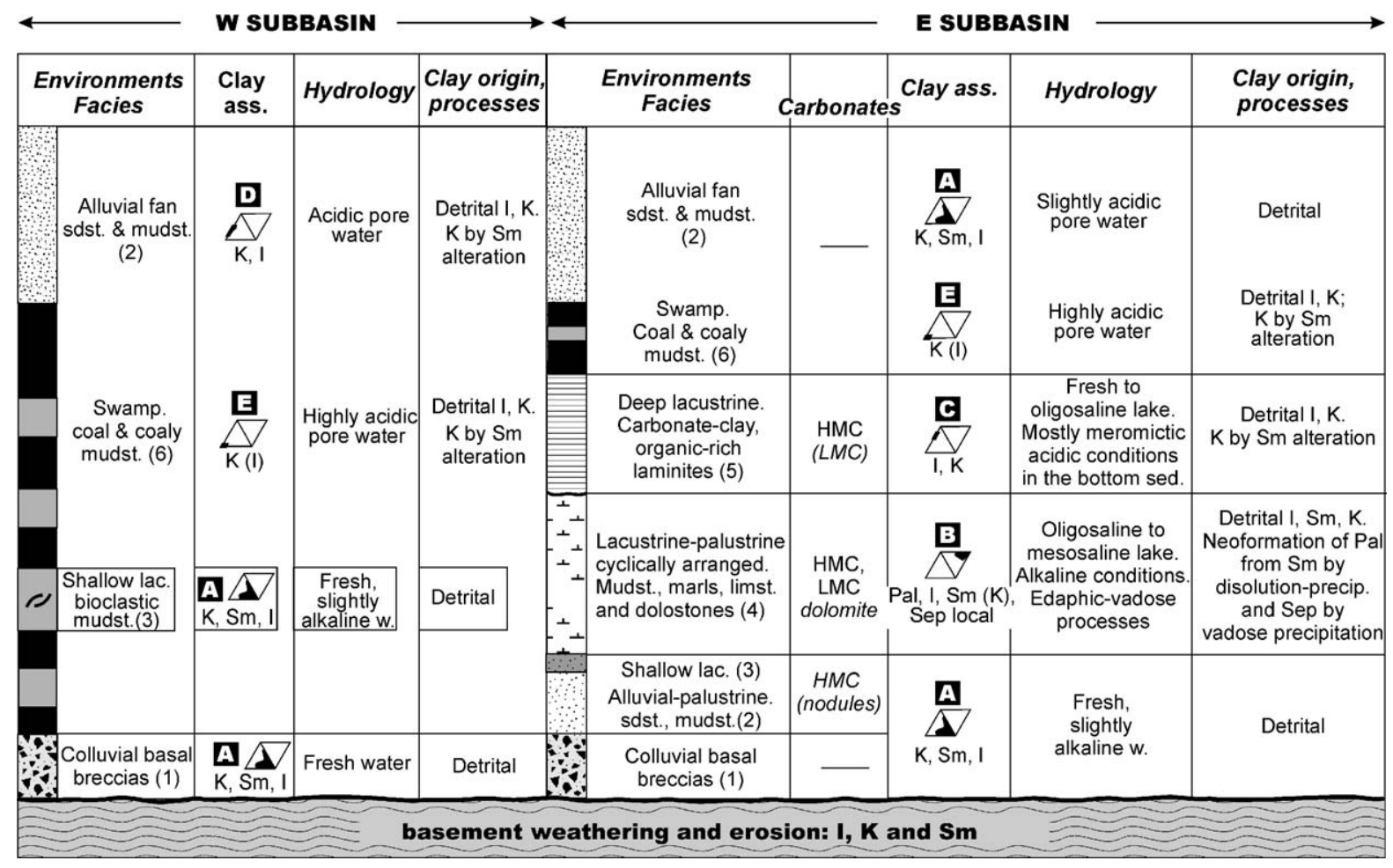

Fig. 9. Summary of the main palaeoenvironmental and early diagenetic conditions, which resulted in the formation of the clay mineral assemblages distinguished in the As Pontes Basin. K, kaolinite; I, illite; Sm, smectite; Pal, palygorskite; Sep, sepiolite. Capital letters A to E and accompanying parallelograms correspond to the clay mineral assemblages in Fig. 7. Numbers correspond to the facies assemblages. 
overlies the basin substratum is the record of the Late Oligocene-Early Miocene weathering products in the As Pontes Basin region. Weathering of slates and schists could contribute directly some illite, whereas additional illite and kaolinite could derive from the hydrolysis of feldspar and mica in the parent rock.

Al-smectite could result from the alteration of clinochlore. According to Murakami et al. (1996) and Gillot et al. (2000), this mineral can be weathered into Al-smectite under mild weathering conditions, which result in magnesium release. Thus, the major occurrence or prevalence of Al-smectite in assemblage A would have resulted from the weathering of clinochlore, which is very abundant in the slates and schists in the basin catchment (Brell and Doval, 1979; Barsó et al., 2000) and extremely scarce in the basin infill.

The clay assemblage A occurs in the alluvial and shallow freshwater lacustrine deposits (facies assemblages 2 and 3). These deposits do not show significant traces of early, pervasive diagenesis. The preservation of carbonate products (i.e. early diagenetic carbonate nodules, gastropod shells) in the siliciclastic facies suggests fresh, near neutral to slightly alkaline pore water conditions. These conditions would allow preservation of the original detrital clay minerals represented by clay assemblage A.

The relative homogeneity of the source rocks prevented large variations in the clay mineralogies of alluvial deposits. Nevertheless, the alluvial deposits that were fed from the northern catchment (wells 642 and 2106) show larger illite and smectite content than those that were supplied from the southern catchment (wells 10010 and 5003), which in turn display larger kaolinite contents. These differences in the relative proportions of the clay minerals probably reflect minor differences between the compositions of the northern and the southern catchment source rocks (Fig. 1) and/or different flushing of these rocks due to local relief or permeability variations (Berner and Berner, 1996). Some of the changes in clay percentages may also be related to mineral selection caused by grain size changes of the clay mineral fraction in the transition to distal alluvial fan zones. Thus, the smectite increase in lower part of the Subunit 1A (wells 5003 and 10010, Fig. 3) may reflect grain size changes in the transition from distal alluvial fan to shallow lacustrine environments (facies assemblage 3).

\subsection{Fiber-clay neoformation under saline and alkaline lacustrine-palustrine conditions}

Several factors favoured the generation of fibrous magnesian clays in the As Pontes Basin: (1) Closed drainage lacustrine conditions gave rise to high silica and magnesium concentrations. The magnesium contribution could be significant initially, resulting from extensive weathering of clinochlore in the source areas. (2) Additional silica was contributed from biogenic sources (e.g. sponge spicules and diatom frustules). (3) Extensive precipitation of primary and early diagenetic calcium carbonates increased the $\mathrm{Mg}$ / $\mathrm{Ca}$ ratio in the basin surface and pore waters. (4) Pore water alkalinity was relatively high, as a consequence of the high carbonate content.

In facies assemblage 4, there is a good correlation between the appearance and further increase of palygorskite and the decline or even absence of smectite, which is abundant in clay assemblage A. Bearing in mind that the average percentages of illite and kaolinite are maintained, this suggests that palygorskite could be neoformed by dissolution-precipitation from smectite, a process already recognised by earlier authors (Jones and Galán, 1988; Inglès and Anadón, 1991; Webster and Jones, 1994; López and González, 1995; López-Galindo et al., 1996).

The presence of sepiolite in palustrine carbonatedominated deposits showing root traces and other pedogenic features suggests that this clay mineral was formed in a vadose setting under the influence of an oscillating water table, characterised by high magnesium and carbonate solute contents. Formation of sepiolite in calcic soil horizons may occur by direct precipitation from concentrated vadose solutions in the absence or complete fixation of aluminium in colloidal solution (Jones, 1983). The presence of sepiolite in the magnesium-rich carbonate beds suggests that its formation was favoured in periods were the lake water was characterised by higher $\mathrm{Mg}^{2+}$ concentration in the presence of $\mathrm{Si}^{4+}$ (Jones, 1983; Webster and Jones, 1994).

There is an extensive literature focused on the formation of fibrous clay minerals (palygorskite and sepiolite) under arid and semiarid climatic conditions 
(Singer, 1984; Jones and Galán, 1988; Chamley, 1989 and citations therein). The occurrence of these minerals is often considered to be closely related to semiarid evaporitic environments where sulphate precipitation takes place. However, the fibrous clay minerals in the As Pontes Basin were not generated under such extreme evaporitic conditions. Closed drainage lacustrine-palustrine environments, submitted to a slightly negative hydrological balance, can also result in magnesium-rich alkaline lake waters, suitable for magnesium-rich clays.

\subsection{Clay mineral transformation under organic matter-rich, acidic conditions}

Suitable conditions for generation of fibrous, magnesium-rich clay minerals in the E-subbasin did not prevail during the deposition of the deeper, organicrich facies of Subunit 1B (facies assemblage 5). The distinctive change of clay mineralogy between clay assemblages $\mathrm{B}$ and $\mathrm{C}$ (Fig. 3) reflects a remarkable environmental-hydrochemical change in the lacustrine depositional framework of the E-subbasin. Greater depth and meromixis in the lake water column resulted in anoxic conditions and in accumulation and preservation of organic matter on the lake floor. This organic-rich environment favoured acidic conditions that enhanced the formation of kaolinite from Alsmectite (Keller, 1970; Staub and Cohen, 1978; Chamley, 1989). As a consequence, only kaolinite and illite were preserved under these conditions.

Clay assemblages D and E are most common in the peat swamp environments that received a variable detrital influence resulting in coaly mudstone and lignite beds. In these environments, where the deposition of the widespread coal seams took place (Unit 1 in W-subbasin and Units 2-5), the early diagenetic conditions were acidic and prone to the generation of early diagenetic kaolinite from the terrigenous smectite and illite. The sharper diffraction peaks shown by kaolinite in As Pontes coals support the early diagenetic transformation of kaolinite from smectite. This is in agreement with the clay assemblage descriptions provided by Chamley (1989) in other organic-rich environments. Therefore, kaolinite is a major, often dominant clay mineral in the swamp-dominated successions and resulted from both primary terrigenous accumulation and early diagenetic transformation.

\section{Conclusions}

The Late Oligocene-Early Miocene As Pontes Basin evolved mainly under a subtropical warm, humid-subhumid climate. No evidence for highly stressing aridity or evaporitic conditions has been recognised either in the depositional or in the palaeobiological record. The basin source area was composed of slates and schists, which yielded kaolinite, illite and smectite. Illite was an original mineral in the source rocks, whereas kaolinite and Al-smectite resulted mainly from weathering of feldspar and clinochlore. This detrital clay assemblage (K, I, Sm) persisted in some colluvial, alluvial fan and shallow lacustrine deposits, which underwent mild early diagenesis under the influence of diluted, poorly evolved pore waters with neutral to gently basic $\mathrm{pH}$ (Figs. 8a and 10).

Closed drainage conditions in the E-subbasin resulted in alternating episodes of high and low solute water concentration. As a consequence, the primary detrital clay assemblage was strongly modified because of a significantly changing lacustrine hydrochemistry. The magnesium-rich clay mineral-dominated assemblage B (Fig. 10) developed in shallow, saline lacustrine and palustrine zones submitted to pedogenesis. High $\mathrm{Mg} / \mathrm{Ca}$ rates, significant silica contribution and high $\mathrm{pH}$ conditions resulted in extensive transformation of Al-smectite into palygorskite, whereas sepiolite was neoformed by direct precipitation (Fig. 10). Elsewhere, acidic pore water conditions, developed in environments with large organic matter accumulation and absence or low concentration of buffering ions, led to the alteration of Al-smectite into kaolinite. This process was relatively mild in the organic matter-rich, meromictic lacustrine bottom floor environment, where assemblage $\mathrm{C}$ was developed. In addition, the same process was very pervasive in peat-accumulation zones, where assemblages D and E developed. Kaolinite acquired stronger crystallinity in the swamp, peatforming environments.

The lateral and vertical transitions among clay mineral assemblages in the As Pontes Basin fill shows that a large variety of clay minerals can form in an area of reduced extent subject to rapid depositional and environmental changes. This emphasises the importance of palaeoenvironmental change in forcing clay mineral transformations in the depositional record. The 


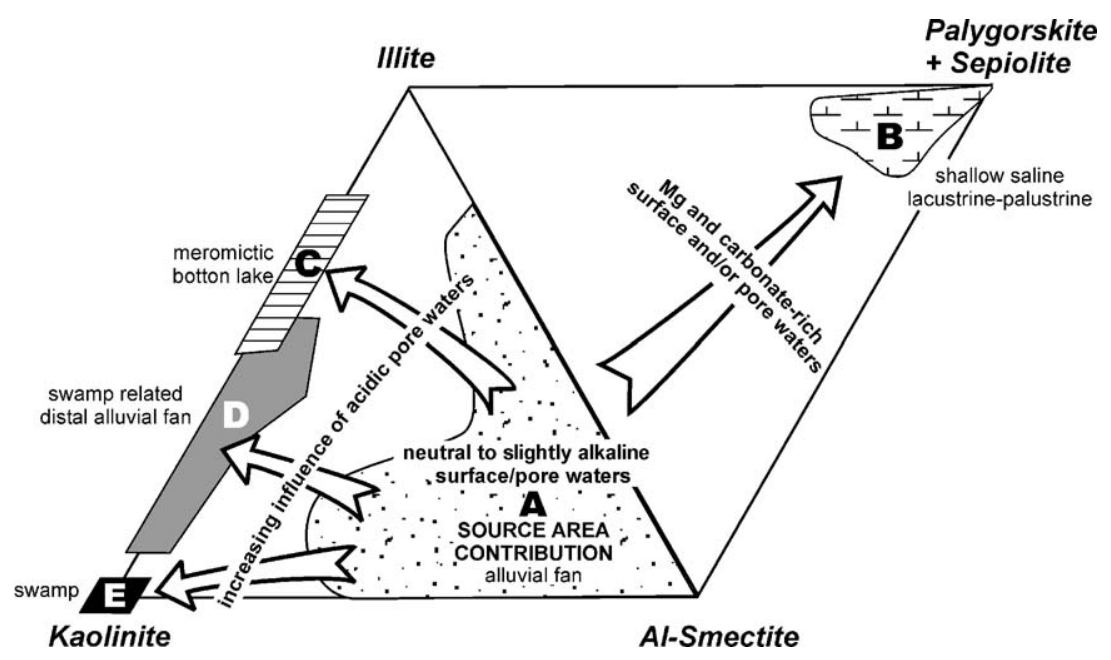

Fig. 10. Diagram showing the genetic relations of the clay mineral associations in the As Pontes Basin (named A to E). Depositional environments and main hydrochemical conditions are also indicated.

interplay between the subtropical, humid-subhumid climate and the tectonic processes in the source areas did not result in major variations of the rather monotonous original clay assemblage fed into the basin. But conversely, this interplay gave rise to a complex environmental-hydrochemical evolution in the depositional zones, which led to drastic changes in clay mineral assemblages (Figs. 8-10).

The As Pontes case study provides clear evidence for the major influence of geomorphic and tectonosedimentary processes on the clay mineral record in nonmarine depositional systems. Autogenic increase in catchment area through headward erosion and beheading resulted in larger water input into the basin, modifying its hydrological balance. Also, faulting and folding affected both the catchment and the drainage of the depositional zones, which in turn influenced the basin hydrological balance. The geomorphic evolution and tectonics interacted with climate, causing dramatic hydrological shifts in the basin, which modified depositional and early diagenetic conditions in alluvial and lacustrine systems and led to very significant changes in the composition of the clay assemblages.

Low-order climatic changes are often interpreted in ancient continental records on the basis of significant, in some cases dramatic, clay mineral assemblage variations. Nevertheless, the As Pontes clay mineral record demonstrates that very different, sometimes coeval, clay assemblages developed in the various basin zones due to tectonically forced palaeoenvironmental changes. These changes are similar to those forced by climate change and could lead to misleading palaeoclimatic conclusions. Consequently, it must be emphasised that, in some cases, the role of climate can be diminished or even obliterated by tectonics. Therefore, integrative understanding of the role of tectonic constrains on palaeoenvironmental basin evolution is advisable in order to avoid misleading interpretation of clay mineral signatures.

\section{Acknowledgements}

This research was funded by the Spanish Ministry of Research and Education and is a contribution to the CICYT projects PB94-0826 and PB97-0882-C03-01. Financial support was also provided by ENDESA, through cooperative projects with the University of Barcelona (Fundació Bosch i Gimpera, projects 207 and 2149). The Grups de Recerca de Qualitat Consolidats of Geodynamics and Basin Analysis and Sedimentary Petrology (SGR 1999-00064 and SGR 2000-00030) also supported this research. X-ray diffraction analyses, TEM and SEM observations and analyses were carried out in the Serveis CientíficoTècnics at the Universitat de Barcelona. The authors are 
indebted to José Pedro Calvo, Keith A.W. Crook and an anonymous reviewer for their critical comments and suggestions.

\section{References}

Anadón, P., 1989. Los lagos salinos interiores (atalásicos) con faunas de afinidad marina del Cenozoico de la Península Ibérica. Acta Geol. Hisp. 24, 83-102.

Andeweg, B., 2002. Cenozoic tectonic evolution of the Iberian Peninsula. Causes and effects of changing stress fields. $\mathrm{PhD}$ Thesis, Vrije Universiteit and Universidad Complutense. Amsterdam.

Armenteros, I., Bustillo, M.A., Blanco, J.A., 1995. Pedogenic and groundwater processes in a closed Miocene basin (northern Spain). Sediment. Geol. 99, 17-36.

Baltuille, J.M., Becker-Platen, J.D., Benda, L., Ivanovic, Y., 1992. A contribution to the subdivision of the Neogene in Spain using palynology. Newsl. Stratigr. 27, 41-57.

Barsó, D., Cabrera, L., Marfil, R., Ramos, E., 2000. Evolución de la procedencia y redes de drenaje de la cuenca terciaria continental de As Pontes (Galicia), a partir del análisis de las modas detríticas y de minerales pesados. Geotemas 1, 151-154.

Berner, E.K., Berner, R.A., 1996. Global Environment: Water, Air And Geochemical Cycles. Prentice-Hall, New Jersey. 376 pp.

Biscaye, P.E., 1965. Mineralogy and sedimentation of recent deepsea clay in the Atlantic ocean and adjacent seas and oceans. Geol. Soc. Amer. Bull. 76, 803-832.

Brell, J.M., Doval, M., 1979. Relaciones entre los sedimentos neógenos de Galicia y las alteraciones de su substrato. Interpretación paleoclimática. Acta Geol. Hisp. 14, 190-194.

Cabrera, L., Jung, W., Kirchner, M., Sáez, A., 1994. Crocodilian and Paleobotanical findings from tertiary lignites of As Pontes Basin (Galicia, NW Spain). Cour. Forsch. Inst. Senckenb. 173, 153-165.

Cabrera, L., Hagemann, H.W., Pickel, W., Sáez, A., 1995. The coal bearing Cenozoic As Pontes Basin (NW Spain): geological influence on its coal's characteristics. Int. J. Coal Geol. 27, 201-226.

Cabrera, L., Ferrús, B., Sáez, A., Santanach, P., Bacelar, J., 1996. Onshore Cenozoic strike-slip basins in NW Spain. In: Friend, P., Dabrio, C. (Eds.), Spanish Tertiary Basins. Cambridge Univ. Press, Cambridge, pp. 247-253.

Chamley, H., 1989. Clay Sedimentology. Springer-Verlag, Berlin.

Chung, F.H., 1974. Quantitative interpretation of X-ray diffraction patterns of mixtures. J. Appl. Crystallogr. 7, 519-531.

Ferrús, B., 1998. Análisis de cuenca y relaciones tectónica-sedimentación en la cuenca de As Pontes (Galicia). PhD Thesis, Univ. Barcelona, Spain.

Galán, E., Carretero, I., 1999. New approach to compositional limits for sepiolite and palygorskite. Clays Clay Miner. 47, 399-409.

Gillot, F., Righi, D., Elsass, F., 2000. Pedogenic smectites in podzols from central Findland-an analytical electron microscopy study. Clays Clay Miner. 48, 655-664.

Guven, N., 1988. Smectites. In: Bailey, S.W. (Ed.), Hydrous Phyllo- silicates. Reviews in Mineralogy, vol. 19. Mineralogical Society of America, Washington, pp. 497-559.

Huerta, A., 1998. Petrografía, Mineralogía y Geoquímica de los lignitos de la cuenca oligo-miocena de As Pontes (A Coruña): Control geológico sobre la calidad del carbón. PhD Thesis, Univ. Barcelona, Spain.

Huerta, A., Parés, J.M., Cabrera, L., Ferrús, B., Sáez, A., 1997. Magnetocronología de las sucesiones cenozoicas de la cuenca de As Pontes (La Coruña, Noroeste de España). Acta Geol. Hisp. 32, 127-145.

Inglès, M., Anadón, P., 1991. Relationship of clay minerals to depositional environment in the non-marine Eocene Pontils group, SE Ebro Basin (Spain). J. Sediment. Petrol. 61, 926-939.

Jones, B.F., 1983. Occurrence of clay minerals in surficial deposits of southwestern Nevada. Sci. Geol., Mem. 72, 81-92.

Jones, B.F., Galán, E., 1988. Palygorskite-sepiolite. In: Bailey, S.W. (Ed.), Hydrous Phyllosilicates. Reviews in Mineralogy, vol. 19. Mineralogical Society of America, Washington, pp. $631-674$.

Karakas, Z., Kadir, S., 1998. Mineralogical and genetic relationships between carbonate and sepiolite-palygorskite formations in the Neogene lacustrine Konya Basin, Turkey Basin. Carbonates Evaporites 13, 198-206.

Keller, W.D., 1970. Environmental aspects of clay minerals. J. Sediment. Petrol. 4, 788-814.

Long, D.G.F., McDonald, A.M., Facheng, Y., Houjei, L., Zili, Z., $\mathrm{Xu}, \mathrm{T} ., 1997$. Palygorskite in paleosols from the Miocene Xiacaowan formation of Jiangsu and Anhui provinces, P.R. China. Sediment. Geol. 112, 281-295.

López, F., González, J.M.G., 1995. Fibrous clays in the Almazan Basin (Iberian range, Spain) - genetic pattern in a calcareous lacustrine environment. Clay Miner. 30, 395-400.

López, N., Fernández, M.T., Peláez, P., De la Peña, A., 1993. Estudio paleontológico en las cuencas terciarias de Galicia. Rev. Soc. Geol. Esp. 6, 19-28.

López-Galindo, A., Ben-Aboud, A., Hach-Ali, P.F., Casas Ruiz, J., 1996. Mineralogical and geochemical characterization of palygorskite from Gabasa (NE Spain) - evidence of a detrital precursor. Clay Miner. 31, 33-44.

Mayayo, M.J., Bauluz, B., González Lopez, J.M., 2000. Variations in the chemistry of smectites from the Calatayud Basin (NE Spain). Clay Miner. 35, 365-374.

Medus, J., 1965. L'évolution biostratigraphique d'une lagune néogène de Galicie (Espagne). Pollen Spores VII, 381-393.

Moore, D., Reynolds Jr., R.C., 1989. X-ray Diffraction and the Identification and Analysis of Clay Minerals. Oxford Univ. Press, Oxford.

Murakami, T., Isobe, H., Sato, T., Ohnuki, T., 1996. Weathering of chlorite in a quartz-chlorite schist. Mineralogical and chemical changes. Clays Clay Miner. 44, 244-256.

Peacor, D.R., 1992. Diagenesis and low grade metamorphism of shales and slates. In: Buseck, P.R. (Ed.), Mineral Reactions at the Atomic Scale: Transmission Electron Microscopy. Reviews in Mineralogy, vol. 27. Mineralogical Society of America, Washington, pp. 335-379.

Plaziat, J.C., 1993. Modern and fossil Potamids (Gastropoda) in saline lakes. J. Paleolimnol. 8, 163-169. 
Sáez, A., Cabrera, L., 2002. Sedimentological and palaeohydrological responses to tectonics and climate in a small, closed, lacustrine system: Oligocene As Pontes Basin (Spain). Sedimentology 49 (6), 1-22.

Schultz, L.G., 1964. Quantitative interpretation of mineralogical composition from X-ray chemical data for the Pierre Shale. U.S. Geol. Surv. Prof. Pap. 391-C, 31 pp.

Singer, A., 1979. The paleoclimatic interpretations of clay minerals in sediments - a review. Earth-Sci. Rev. 21, 251-293.

Singer, A., 1984. The palygorskite in sediments: detrital, diagenetic or neoformed - a critial review. Geol. Rundsch. 68, 996-1008.

Smith, A.G., 1996. Cenozoic latitudes, positions and topography of the Iberian Peninsula. In: Friend, P.F., Dabrio, C.J. (Eds.), Ter- tiary Basins of Spain. Cambridge Univ. Press, Cambridge, pp. $6-8$.

Staub, J.R., Cohen, A.D., 1978. Kaolinite-enrichment beneath coals; a modern analog, Snuggedy Swamp, south Carolina. J. Sediment. Petrol. 48, 203-210.

Van der Marel, H.W., 1966. Quantitative analysis of clay minerals and their admixtures. Contrib. Mineral. Petrol. 12, 96-138.

Webster, D.M., Jones, B.F., 1994. Paleoenvironmental implications of lacustrine clay minerals from the double lakes formation, southern high plains, Texas. In: Renaut, R.W., Last, W.M. (Eds.), Sedimentology and Geochemistry of Modern and Ancient Saline Lakes. SEPM Spec. Publ. 50, 159-172. 